\title{
Economic effects of coronavirus outbreak (COVID-19) on the world economy
}

\author{
Nuno Fernandes \\ Full Professor of Finance \\ IESE Business School \\ Spain \\ nfernandes@iese.edu
}

Preliminary and subject to revisions as new data is released

Revised, April 13, 2020

Version 2.0 


\section{Contents}

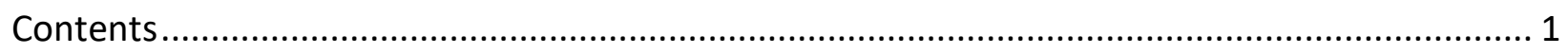

Executive summary: Global recession is almost inevitable .................................................... 2

1. Mortality rates and economic impact are not correlated ................................................ 3

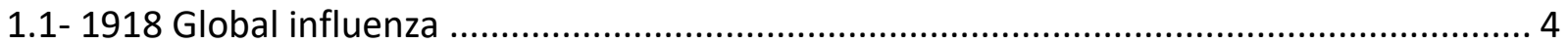

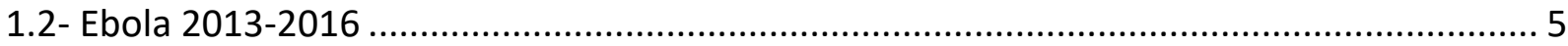

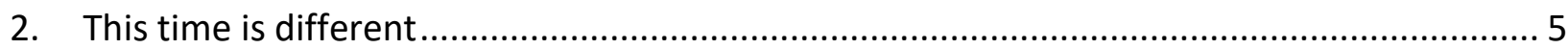

2.1- Relevant business and economic news and data ................................................. 6

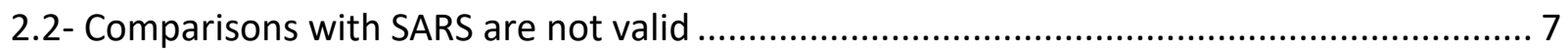

2.3- The second quarter will be worse than the first...................................................... 10

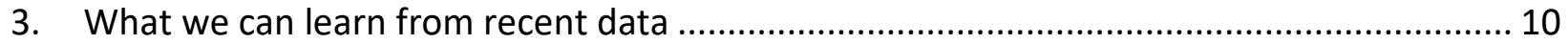

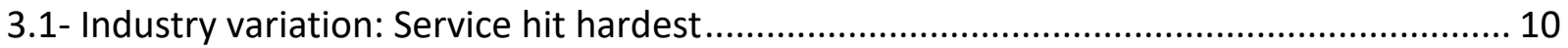

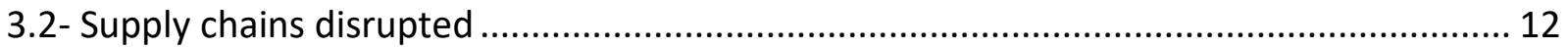

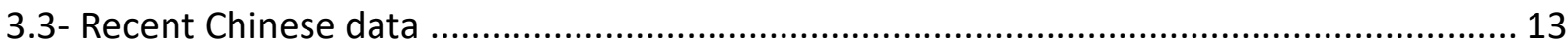

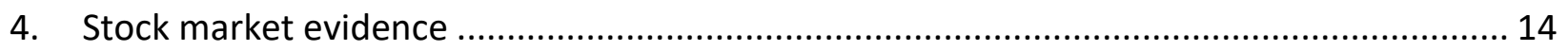

4.1- Markets around the world are significantly down ..................................................... 15

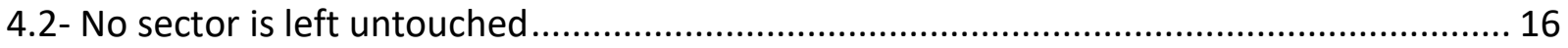

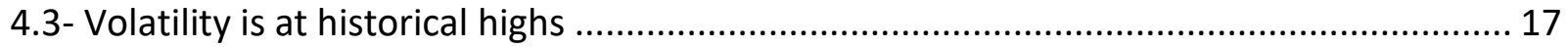

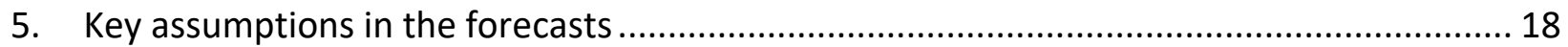

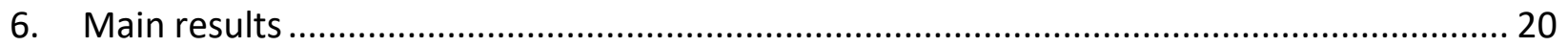

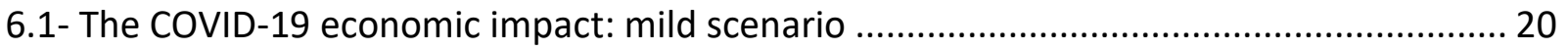

6.2- Estimated GDP growth for different countries ...................................................... 22

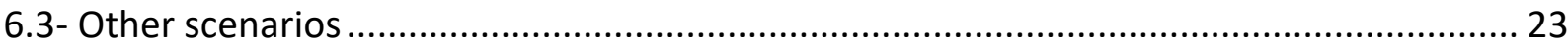

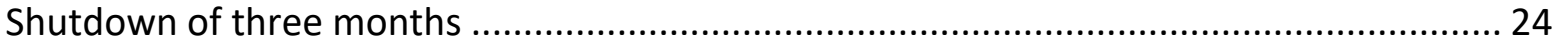

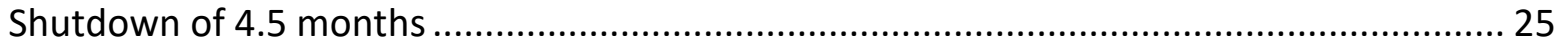

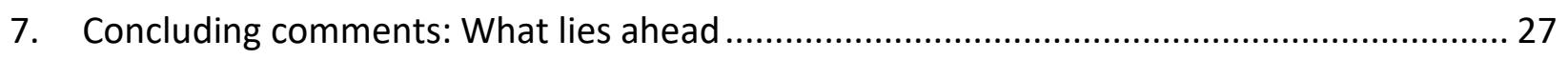

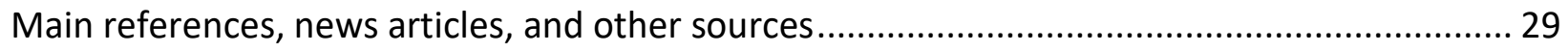




\section{Executive summary: Global recession is almost inevitable}

This report discusses the economic impact of the COVID-19 crisis across industries, and countries. It discusses the economic channels through which economic activity will be impacted. And the asymmetric results across countries and industries. It also attempts a rough estimate of the potential global economic costs of COVID-19 under different scenarios.

The COVID-19 outbreak started in December 2019 in Wuhan city in China. It continues to spread across the world. At the time of the first draft of this report, almost 200,000 cases of the virus had been recorded worldwide. As of this current version, the total has risen to above one million. And more than 100,000 have died.

While some countries have been able to treat the reported cases effectively, it is uncertain where and when new cases will emerge. Every day more cases are reported, and new countries enter the World Health Organization's (WHO) list of areas where the virus has been reported. It seems, however, as if the cases reported from China have peaked, and are now falling. The opposite trends are seen in Europe and America. Given the public health risk, the WHO has declared an emergency of international concern.

In a strongly connected and integrated world, the impacts of the disease go way beyond mortality. As such, governments around the world have been preparing contingency plans, and aid packages to sustain their economies.

In China, we have seen severe lockdowns. This has led to a decrease in consumption, and interruptions to production. Overall, the functioning of global supply chains has been disrupted, affecting companies across the globe. Millions of people could lose their jobs over the coming months. In addition, every day we hear worrying news about more companies shutting down operations, revising estimates, or announcing layoffs. Consumers have also changed their consumption patterns, resulting in shortages of many goods in supermarkets around the world. Global financial markets have registered sharp falls, and volatility is at levels similar, or above, the financial crisis of 2008/9. 
In the middle of all this turbulence, the International Monetary Fund (IMF) has developed some new estimates for growth in 2020 (Feb 2020). In its revised estimates, the IMF expects China to slow down by 0.4 percentage points, as well as a slowdown of global growth by 0.1 percentage points. The OECD also revised their estimates in early March. It forecasted global economic growth falling to $2.4 \%$ for the whole year, compared to $2.9 \%$ in 2019 . I believe both estimates will be proven wrong, and will likely be revised down in the coming months.

There is still time for global policy makers to have a coordinated policy response to the virus and its economic impacts. However, time is running out. Post-World War II, the average recession has increased the unemployment rate by about 2 percentage points. We live now in a very different world compared with those that faced previous crises. Therefore, comparisons are dangerous, and prone to errors. This time, we are facing a combined demand and supply shock, and economic tools are limited. In addition, central banks exhausted their firepower during the good times. There is almost no room for monetary stimulus to help sustain the coming risks. Overall, the potential impacts of this crisis are larger than any previously seen in history.

This report first discusses why comparisons with prior events are not possible. Then, it summarizes the existing news and reliable data that can guide any forecast. Within this, this report concludes that there will be a very asymmetric impact across sectors. Depending on the economic structure of each country, some will be more affected than others. For instance, countries with more service-oriented economies will be more affected, and have more jobs at risk. This report then outlines some possible scenarios, and their impact on economic prospects. Finally, it concludes with a summary of the findings and some policy implications.

\section{Mortality rates and economic impact are not correlated}

There are many channels through which an infectious outbreak influences the economy. The traditional approach to evaluating the economic damages of an outbreak uses information on deaths and illness to estimate the loss of future income due to death and disability. Losses of 
time, income, and direct expenditure on medical care are also part of the traditional measures of economic costs.

This traditional health economics approach underestimates the true costs of the current crisis. We have seen that in prior infectious diseases for which there is no vaccine (e.g., SARS, HIV/AIDS, and pandemic influenza). However, the available evidence from these prior outbreaks provides some information that can help us start thinking about the full implications of COVID-19.

Data from SARS, as well as the Spanish Flu from 1918, provides us with some idea of the economic shocks posed by the current outbreak.

However, it is important to highlight the differences. We are facing a different shock here. In the COVID-19 crisis, the evidence suggests there is no correlation between economic impact and mortality rates. The reaction of governments, companies, consumers and media, have all created a simultaneous demand and supply shock. At the date of this report, I believe the health risk is not necessarily correlated with the economic risk to the global economy.

\section{1 - 1918 Global influenza}

Some of the worst-case scenarios for the current pandemic are based on the global influenza of 1918, which killed 40 million people worldwide in 1918 and 1919. Only the Black Death (14th century) has killed more people (roughly 60 million) over a similar time period. The 1918 global influenza infected one third of the world population. If a similar contagion occurred today, with a much larger population, and with quicker travel times around the world, it could lead to more than 80 million deaths. In addition to tragic levels of mortality, this pandemic caused panic, and seriously impacted the global economy and trade. Some believe that a repeat of the 1918/19 flu pandemic could cost more than $\$ 4$ trillion.

A study by the U.S. Congressional Budget Office (2005) examined two scenarios of pandemic influenza for the United States. A mild scenario (attack rate of $20 \%$; mortality rate of $0.1 \%$ ) and a more severe scenario (attack rate of $30 \%$; mortality of $2.5 \%$ ). According to that study, the GDP 
contraction for the United States would be 1.5\% for the mild scenario and 5\% of GDP in the severe scenario. Similarly, the World Bank has estimated that a global influenza akin to the one in 1918 would cost the economy US\$ 3 trillion, around $5 \%$ of gross domestic product (GDP). And in a mild scenario, the cost would be $2.2 \%$ of GDP.

\section{2- Ebola 2013-2016}

Given the uncertain nature of an influenza pandemic, comparisons with other recent outbreaks have been performed. Chief among them is the Ebola outbreak in Africa. This 2013-2016 Ebola virus disease outbreak led to about 11,300 deaths.

In terms of economic impact, there are estimates of:

O US\$ 53 billion loss from the economic and social impact of Ebola in West Africa

○ $20 \%$ drop in Sierra Leone's GDP in 2015

This outbreak has also taught us, that even when the health impact of an outbreak is relatively limited, its economic consequences can be devastating and long-lasting. As an example, Liberia's GDP declined 8 percentage points from 2013 to 2014, even as the country's overall death rate fell over the same period.

\section{This time is different}

Comparisons with other global crises, like the 2008 financial crisis, are not possible. This time we are facing a number of new challenges, which prevent simple comparisons with the past:

It is a global pandemic

O It is not focused on low-middle income countries

- Interest rates are at historical lows

- The world is much more integrated

- This current crisis is generating spillover effects throughout supply chains

- We have simultaneously destruction of demand and supply 


\section{1- Relevant business and economic news and data}

The above-mentioned facts can be seen in the light of recent business events. Unfortunately, the economic impact of the current health crisis is being felt across sectors and countries. This is a small sample of relevant events over the past month:

- Car manufacturers, such as Volkswagen and Ferrari, suspend production in Europe

- Sectors affected by the lockdown-transport, entertainment, retail, hotels and restaurants-account for a quarter of Italian GDP

- Euro 2020, Tokyo Olympic Games, postponed to 2021

- Tourist destinations like Paris, Madrid, Venice and Rome are deserted

- Trade fairs and events are canceled

○ In the U.S., job losses reached an unprecedented high.

- Cancellations of public gatherings and sporting events

- Cruise operators cancelling cruises

- Airlines have started by grounding their Airbus A380s fleets. Later, they grounded their whole fleet

- Airlines asking employees to take two months unpaid leave

- NBA, football leagues, Formula 1 suspended until further notice

- Maersk canceled 50 sailings over coronavirus

- More than 10 million people have already lost their jobs in the U.S.

- Canada's Cineplex Inc. is closing all of its 165 movie theatres

- McDonald's closes seating areas in the U.S.

- Lufthansa reduces $90 \%$ of its long range flights and cancels more than 23000 flights until the end of April

- Media groups, and TV networks are facing sudden drops in ad revenue

- Lockdown of Manila (13 million people in the metropolitan area)

- Amazon and Facebook have issued lower estimates of ad revenue

- Germany has offered companies "unlimited" loans to stop them from collapsing

- Airbus suspended production in France and Spain 
- Gucci and Hermes, luxury goods companies, are closing all their manufacturing sites

- Italian shipyard Fincantieri has asked its workers to use their annual vacation time

- 145 drivers have been laid off at the Port of Los Angeles, as ships from China stopped arriving

- Norwegian Air to cancel $85 \%$ of flights and lay off $90 \%$ of staff

- German tourism giant TUI has made a request for state aid

- MGM closes all U.S. casino resorts

- Switzerland is open only to citizens, residents, and commuters

- Trading on the NYSE halted several times over the past month, as circuit breakers kept being broken

- Swiss watch manufacturers are facing disrupted supplies of components

- Borders are being reinstated within the EU

\section{2- Comparisons with SARS are not valid}

In 2002/3 the outbreak of severe acute respiratory syndrome (SARS) spread from Guangdong, in China, to other Asian countries. By the time it was contained (summer of 2003), more than 8,000 people had been infected, and over 900 people had died (WHO). It led to a 0.5 to 1 percentage point reduction in China's growth in 2003. Overall, the cost of SARS to the global economy is estimated to have been $\$ 54$ billion, according to the World Bank.

There is still plenty of uncertainty about COVID-19. The available data suggests it is more contagious than SARS, similar to the Avian flu. On the other hand, COVID-19 has a much lower mortality rate (between $2-4 \%$ ) compared to SARS (10\%). And both are much lower than the Avian flu $(60 \%)$.

Despite sharing similarities from a medical perspective (both are coronavirus infections), their economic impacts are bound to be very different. As such, comparisons with SARS have to be properly adjusted:

- China represented $3 \%$ of the world economy in 2003. Now it is above $16 \%$. Nowadays, any shock to Chinese activity is strongly felt in markets around the world, in all different sectors. 
- China is currently the world's largest importer and exporter. In many individual industries, China is the main supplier of parts. So, countries that rely on China for intermediate inputs are strongly affected. Companies like Apple and Nike have already admitted being affected by this.

- China is also, in many industries, the main purchaser of global goods and services.

- Since 2014, China has been the largest source country of international tourism (World Tourism Organization). That means that many countries exports of services depend substantially on Chinese consumers.

- The world economy is much more integrated than it was 15 years ago. So economic disruption in one location has much larger spillover effects.

- China represented approximately $40 \%$ of the world growth in 2019. In 2003, China slowing down $1 \%$ of its growth was not noticeable. Nowadays, it has a much bigger impact in global growth.

Figure 1: China's role in world's exports

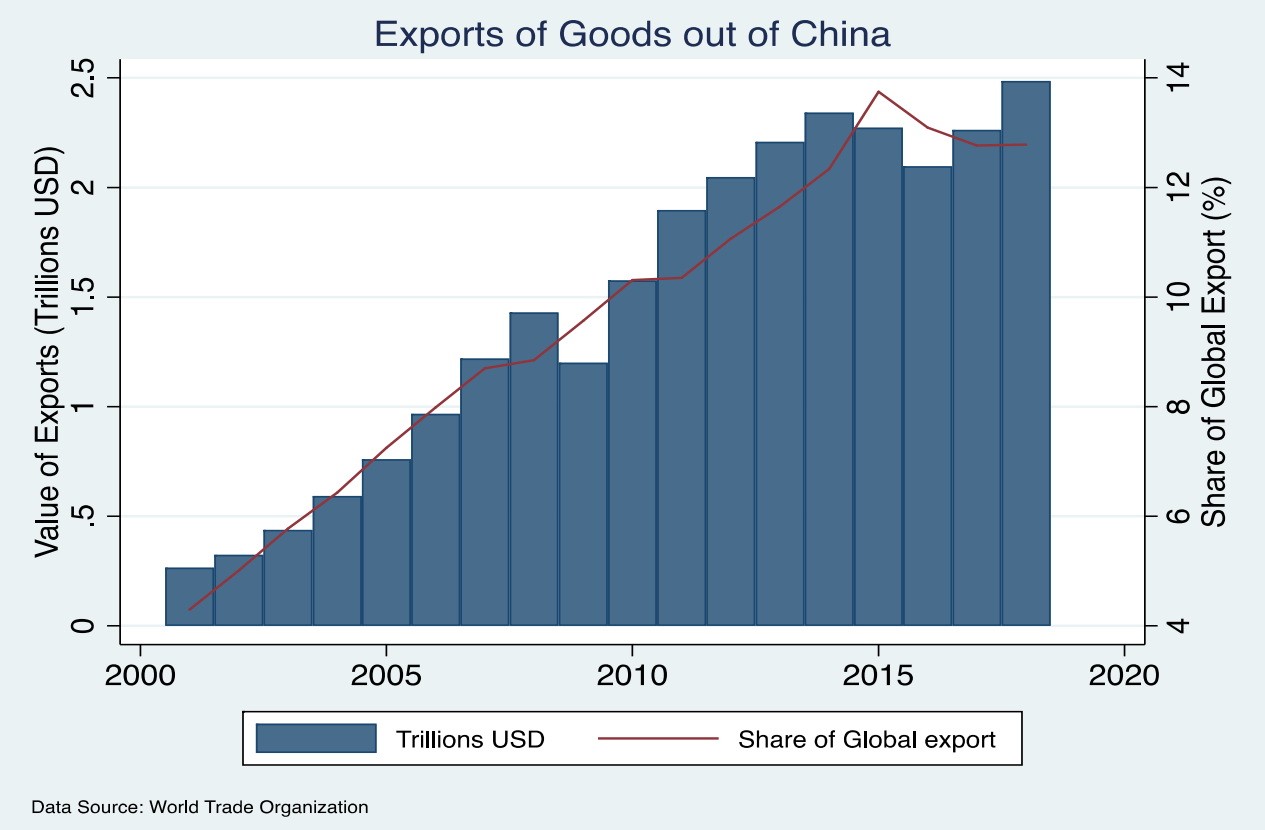


Figure 2: China's role in world's imports

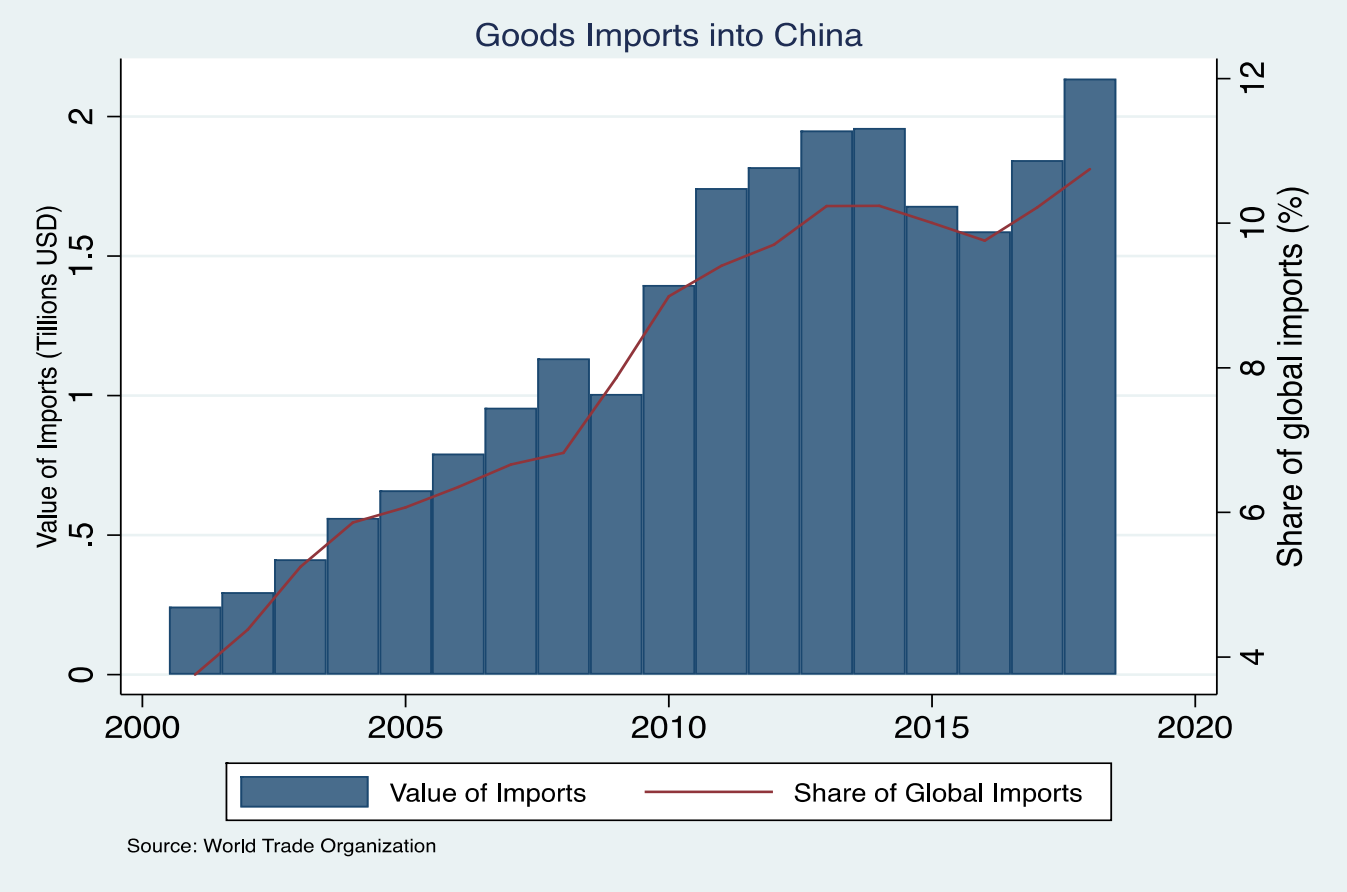

Figure 3: China's contribution to global GDP

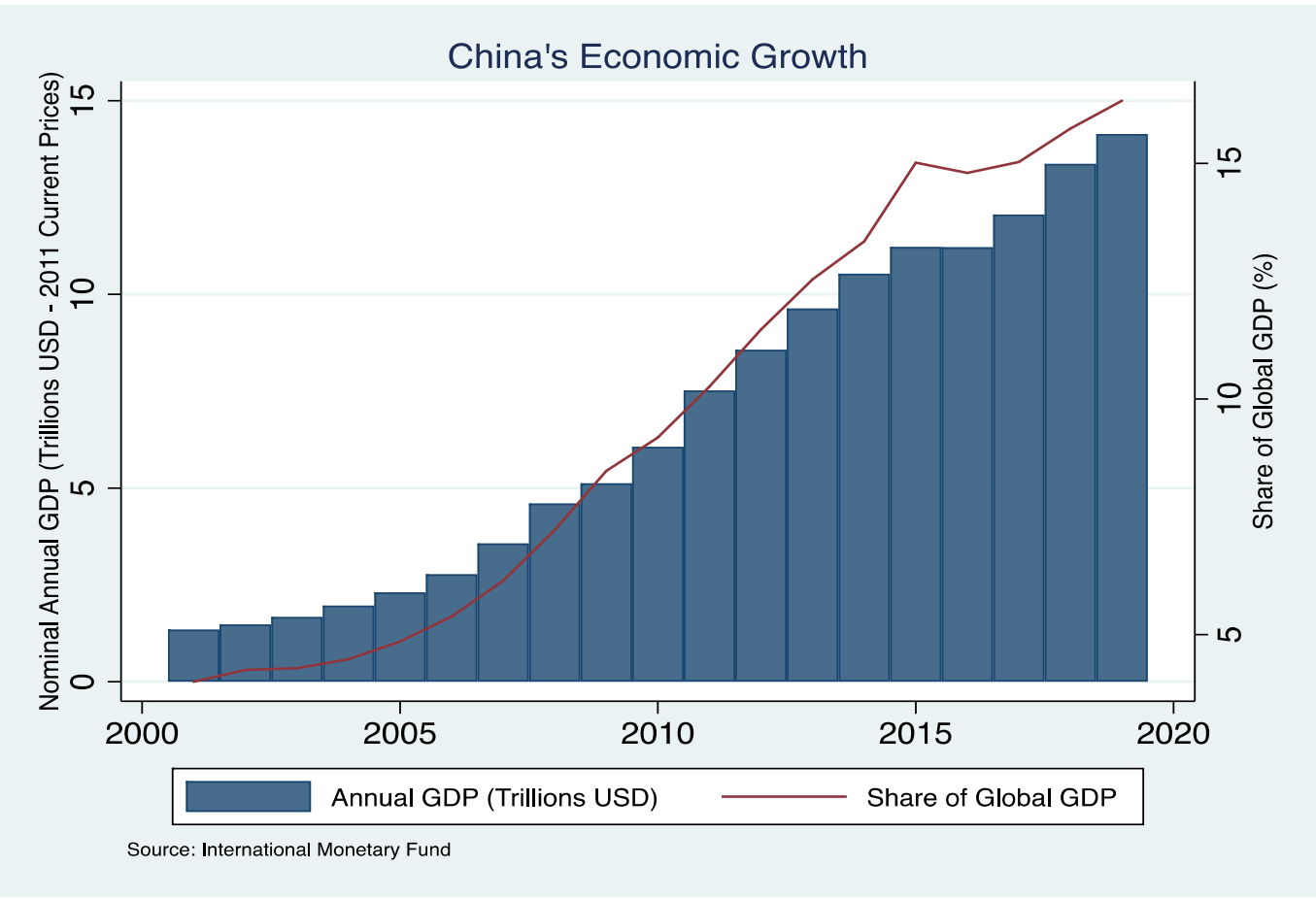


These graphs clearly show that any comparison with 2003 is not relevant. China's role in the global economy has grown significantly since then. And thus, spillover effects occur through trade and supply chains (see sections 2.1- Relevant business and economic news and data and 3.2Supply chains and global trade are disrupted).

\section{3- The second quarter will be worse than the first}

The recent evidence shows China's GDP has decreased in the first quarter. Since China is approximately $16 \%$ of the global economy, that is bad news for the whole world. Prior to the crisis, the estimated GDP growth in China for the first quarter of 2020 was $6 \%$.

As of today, we are entering into a global pandemic scenario. Over the past month, all over the world, we have started to have restrictions put on public life. Countries followed the example of China: lockdowns, mobility restrictions, massive quarantine hospitals, increase in public health measures, protection of the elderly, etc. There are also limits on travel, companies are sending their workers home, airplanes are grounded, etc.

The reality is that most western countries are 1.5-2.5 months behind China in terms of the outbreak. They are also behind in terms of the implementation of corrective measures, and it is doubtful whether the confinement efforts will be as successful as in China.

Therefore, it is guaranteed that the second quarter will be worse than Q1 in the majority of countries worldwide. Recent evidence from the end of Q1 confirms this. In the U.S., more jobs were lost (more than 10 million) during the last two weeks of March, than during the 2008-2010 crisis. In the last week of March, 6.7 million U.S. workers filed for unemployment benefits previous maximum was less than $700.000 \ldots$.

\section{What we can learn from recent data}

\section{1- Industry variation: Service hit hardest}


Several countries are in lockdown mode, for an indefinite time. People are working from home, or simply not working. We are facing travel bans, sporting event cancellations, and prohibitions on gatherings. People in Europe are not using public transport and are avoiding public spaces, such as restaurants, shopping centers, and museums.

All sectors will be affected. There is evidence that discretionary spending by consumers has collapsed. However, according to the data shown in previous sections, the consequences of COVID-19 will not be equally distributed throughout the economy.

The problems are particularly bad in hospitality related sectors. Indeed, the global travel industry-from airlines to cruise companies, from casinos to hotels-is facing reductions of activity of more than $90 \%$. As described in previous sections, tourist destinations are deserted, airlines are grounding fleets and firing staff, trade fairs and cruises are being cancelled, hotels and casinos closing all operations....

Besides these, there are other businesses that rely on tourism and will suffer spillover effects. On top of travel restrictions and quarantines, companies are cancelling travel and meetings, and governments have closed borders. Additionally, it is well known that Chinese tourists are the world's biggest spenders. Figure 4 shows the distribution of travel and tourism's total contribution to GDP in different countries.

Figure 4: Tourism's importance in different countries

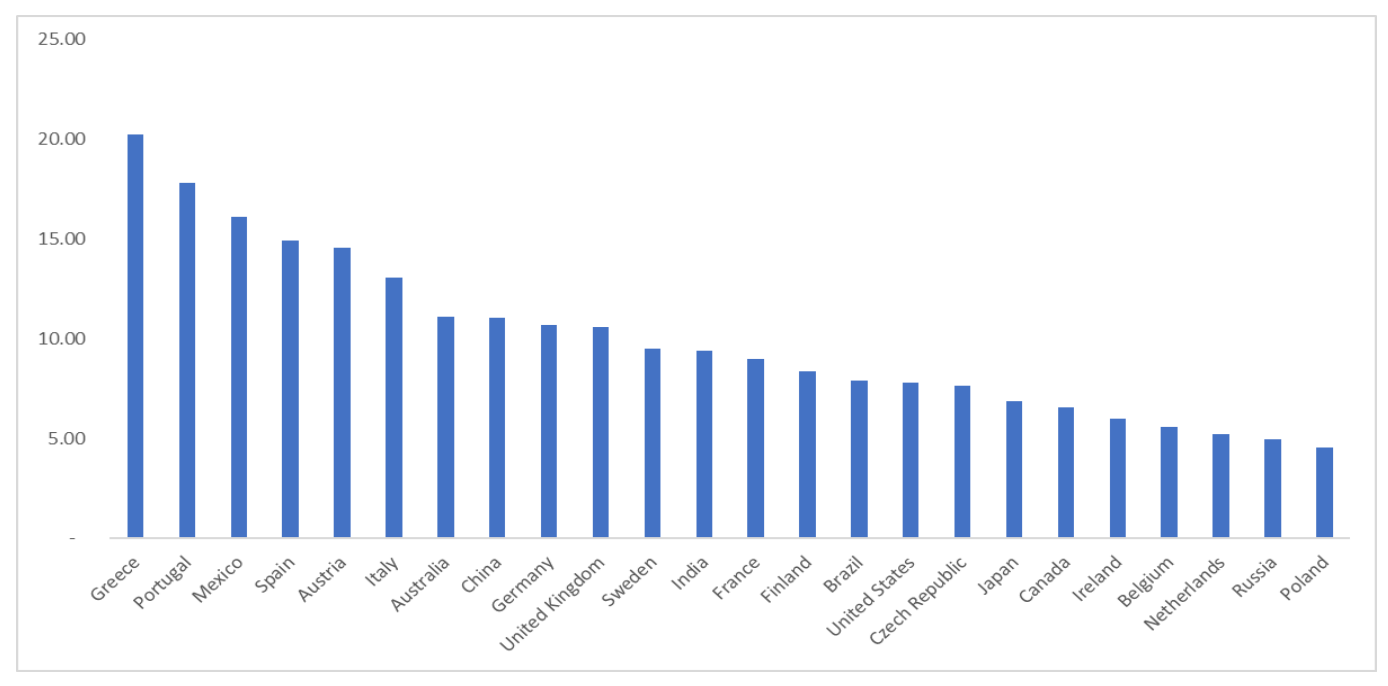

Source: World Travel \& Tourism Council 
A substantial drop in travel affects many world destinations substantially. Obviously, countries like Greece, Portugal, Mexico or Spain that are more reliant on tourism (more than 15\% of GDP) will be more affected by this crisis.

Despite globalization, much activity remains local. Many of the services we use on a daily basis are not traded and remain locally sourced. Here too, there is a strong negative impact to the economy. As people cancel appointments at the dentist, postpone their haircuts, do not go out for their weekly meal, or wait to put their house on the market, this is a strong blow to serviceoriented economies. Indeed, in service sectors, the majority of the lost output is never going to be recovered. If you are thinking of buying a mobile phone or a microwave, you are likely going to wait and buy that product later (assuming this shock is temporary and you still have a job and available income when it's over). However, if you do not go out to restaurants for your weekly dinner during this shut-down, it is very unlikely that you will start to have dinner out every day when the COVID-19 crisis disappears, to make up for the "lost dinners." Nor will you cut your hair twice in the same week.

\section{2- Supply chains and global trade are disrupted}

Supply chain networks is another channel through which the COVID-19 negatively impacts the global economy. As evidence from different markets confirms, the functioning of global supply chains has been disrupted by the current crisis. And this is generating spillover effects throughout different levels of supplier networks.

Global trade in 2020 will fall in every region of the world, and will affect all sectors of the economy. This will impact countries that are strong exporters (no output for their local companies), but also those that are importers (lack of raw materials). The World Trade Organization (WTO) expects global trade to fall up to $32 \%$ this year due to the coronavirus pandemic.

Car companies are shutting operations for lack of parts. This is happening in most industrial sectors. Even in luxury goods, like Swiss watches, manufacturers are facing disrupted supplies of components. 
The disruption to supply chains will increase the cost of business for manufacturing companies. Companies-like toy manufacturer Hasbro, which source almost $70 \%$ of its products from China-are suffering. As factories shut down in China and transportation routes collapse, it has been increasingly difficult for a company like Hasbro to get its products to market.

According to the U.S. Institute for Supply Management, 75\% of companies report disruptions in their supply chains. Also according to this survey, lead times have doubled for many U.S. companies. In addition, there have been shortages of raw materials and final products. This is all exacerbated by the shortage of air and ocean freight options to move products around the world.

The damage is real. Of course, this is questioning the just-in-time strategy of many companies, who try to minimize inventories at all costs. The trade-off between efficiency and resilience has been clear now to many managers. Understandably, some companies prefer to have facilities (or suppliers) in various countries as a risk minimization strategy, even if this means a slightly higherthan-average cost.

\section{3- Recent Chinese data}

Chinese officials said that the peak of the pandemic has passed. However, most believe it will take months before China's economy returns to normal. The spread of the virus around the world is also creating fears of a global recession, which further decreases the demand for Chinese products.

The most recent data from the National Bureau of Statistics showed how the majority of analysts were wrong and underestimated the impact of the crisis. This recently released data indicated that industrial output fell, in the first two months of 2020 , by more than $13.5 \%$. The median forecast of analysts polled by Reuters predicted a gain of $1.5 \%$.

Similarly, investment in fixed assets fell $25 \%$ year-on-year. Here, analysts were forecasting $2.8 \%$ growth (compared with $5.4 \%$ growth in the prior period). 
Chinese consumers respected the lockdowns and their authorities' recommendations. They were fearful of the virus, and thus moved away from shopping malls, restaurants and movie theatres. As a result, retail sales collapsed by $20 \%$, compared with a forecast of $0.8 \%$ by analysts (and very far from the $+8 \%$ growth in December).

Data released on March 16, 2020 indicated that 5 million people in China lost their jobs in January and February (CNBC). But it's likely the figure will grow to more than 9 million (Economist Intelligence Unit).

Infrastructure investment was also down in the first two months (30\% from a year earlier). This is despite local governments' paying for a number of projects through their bonds sold since the start of the year (\$140 billion).

It is important to know that 2020 also marks the end of China's current five-year development plan. Within this plan, there was an objective of doubling the size of the Chinese economy by 2020 (relative to 2010). In order to do that, growth above 6\% was needed for 2020.

The authorities are trying to maintain stable growth expectations through economic stimulus. However, businesses' capital expenditures and consumer spending can ultimately create challenges in pushing for the target GDP level. Indeed, even as the economy starts to work again, three months after the outbreak, businesses are still not operating at normal capacity. As an example, the average Chinese SME is at a $60 \%$ work rate.

It is also now clear that the COVID-19 has spread globally, which will dampen demand globally and mean less demand for Chinese products.

\section{Stock market evidence}

Stock markets collapsed in March 2020. Most stock indices around the world have registered their biggest one-day falls on record. For example, the Dow Jones Index registered the worst ever one-day fall $(2,977$ points on March 16, 2020). And several well-known companies have seen their share prices fall by more than $80 \%$ in a few days. 
Figure 5: S\&P 500 performance over the last 4 years

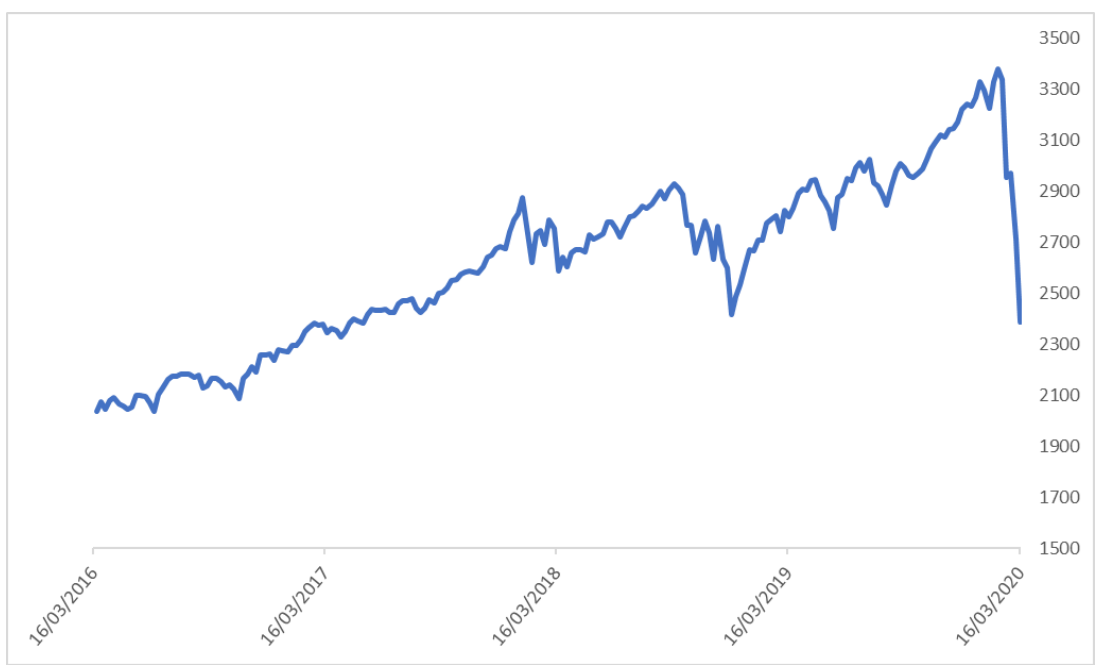

Source: Reuters Eikon

Figure 5 shows the performance of the U.S. stock market. After a strong bull market, the index is now $30 \%$ below its peak. At the current valuation levels, we are back to the pre-Trump era, at levels last seen in early 2016. And the U.S. is not alone.

\section{1- Markets around the world are significantly down}

Figure 6 shows the year-to-date decreases in stock markets for selected countries. The U.K. and German stock markets have seen even worse performances than the U.S. (U.K. -37\%, Germany $33 \%)$.

Figure 6: Global stock markets' performances in 2020

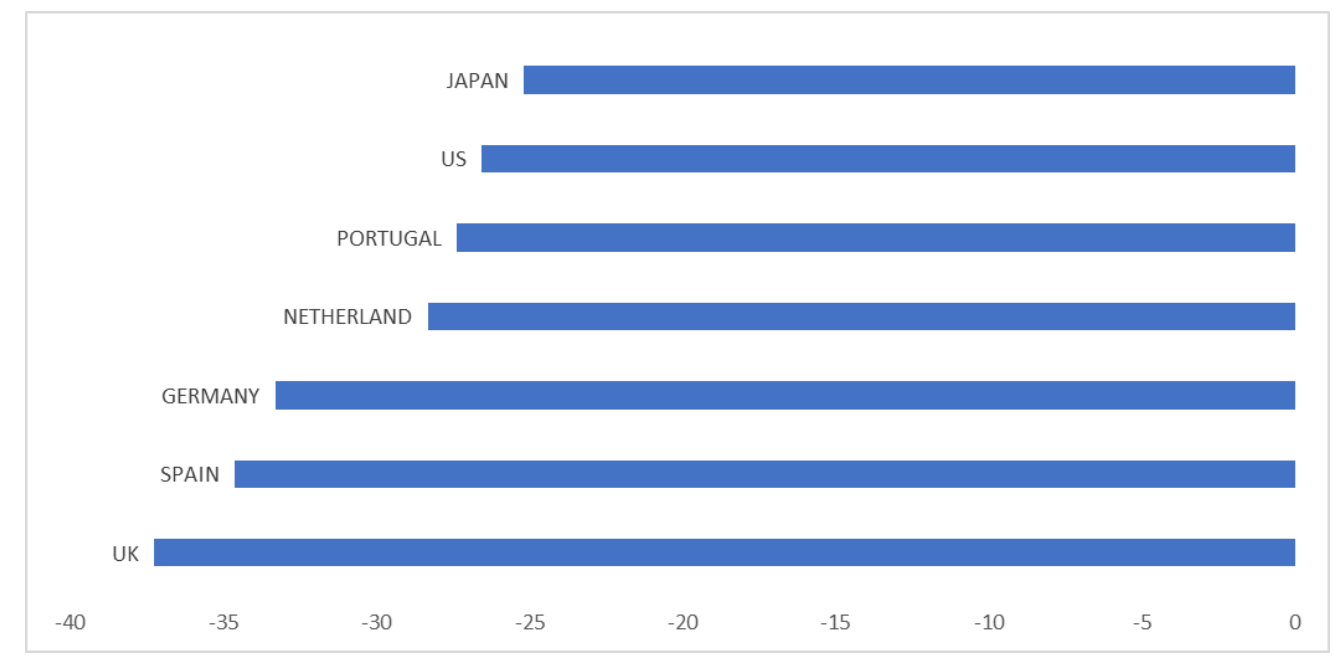

Source: Reuters Eikon 
Figure 7 shows the top 10 worst-performing stock markets. Brazil is down by $48 \%$, Poland by $38 \%$.

Figure 7: Top 10 negative performances - Global stock markets' performances in 2020

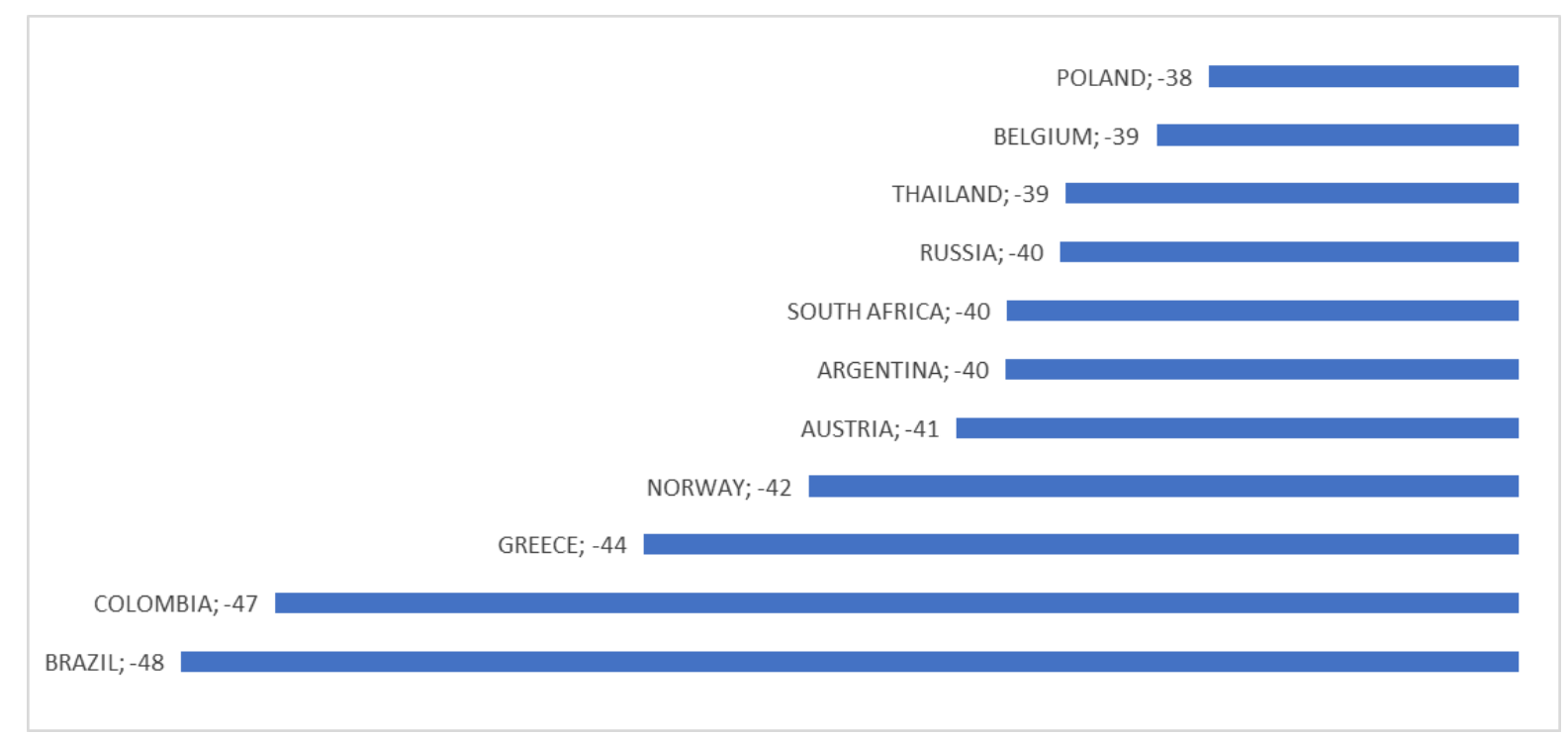

Source: Reuters Eikon

4.2- No sector is left untouched

Figure 8: World stock markets - Different sectors returns in 2020

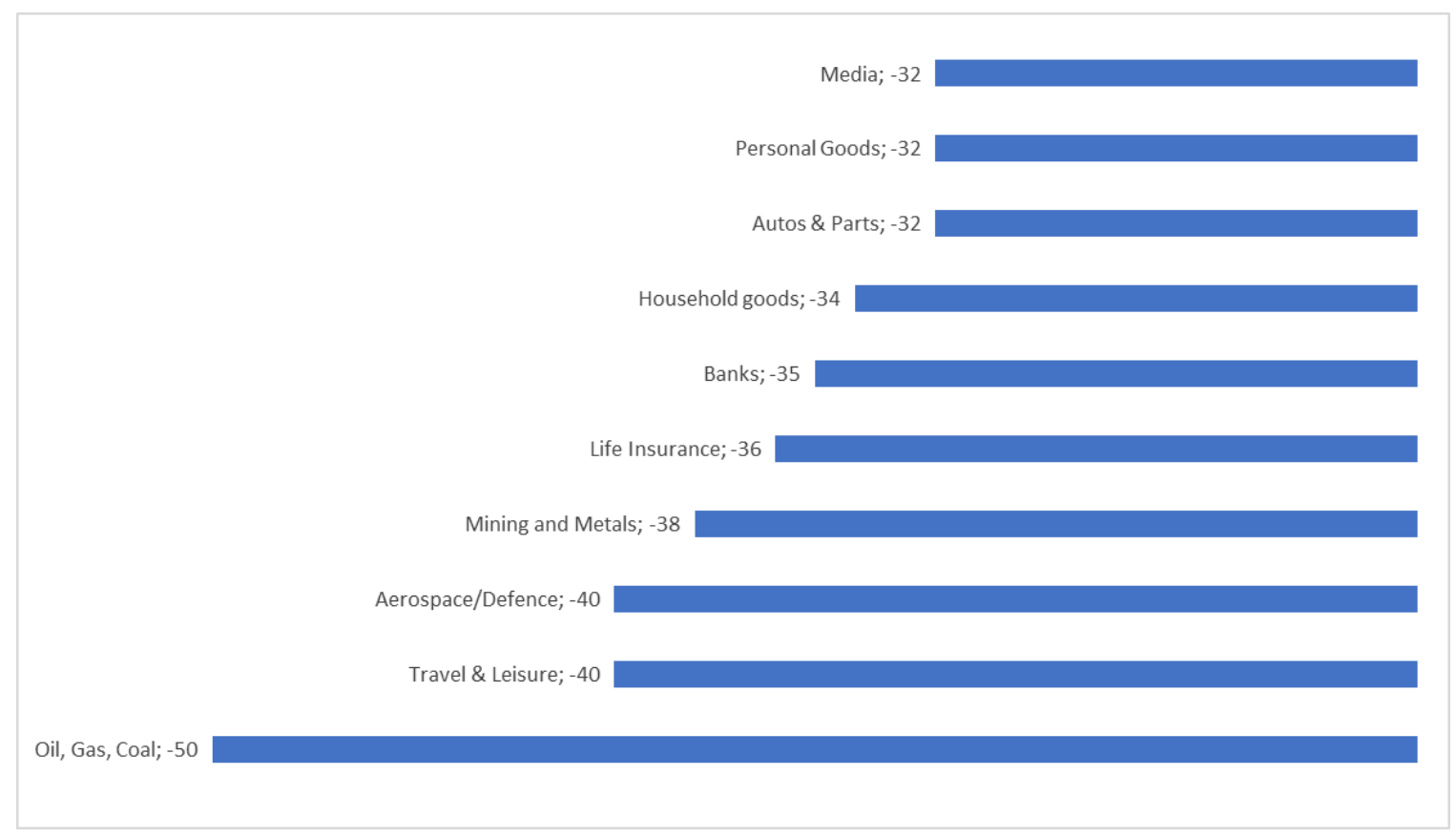

Source: Reuters Eikon 
Figure 8 shows the year-to-date stock returns for industries that have been hit particularly hard since the COVID-19 outbreak. Oil, gas, and coal firms lead the negative returns (on average $50 \%$ below start-of-the-year prices) driven largely by a plunge in oil prices and a decline in global consumption. As expected, travel \& leisure (including hotels, restaurants, etc.), aerospace, mining, banks, and media are all examples of sectors that have fallen by more than $30 \%$.

No sector has been left unharmed by this collapse in stock prices. Even traditionally stable sectors (like utilities, tobacco and pharmaceuticals) are all down by $20 \%$ or more.

\section{3- Volatility is at historical highs}

The implied volatility of equity markets is often used as an indicator of how risky the current environment is-and how uncertain the future is. For instance, the VIX index is commonly referred to as the "fear index." It is based on the traded prices of options on the S\&P 500 index and represents the market expectation of stock volatility over the next 30 days.

Figure 9: Implied volatility given by the VIX index.

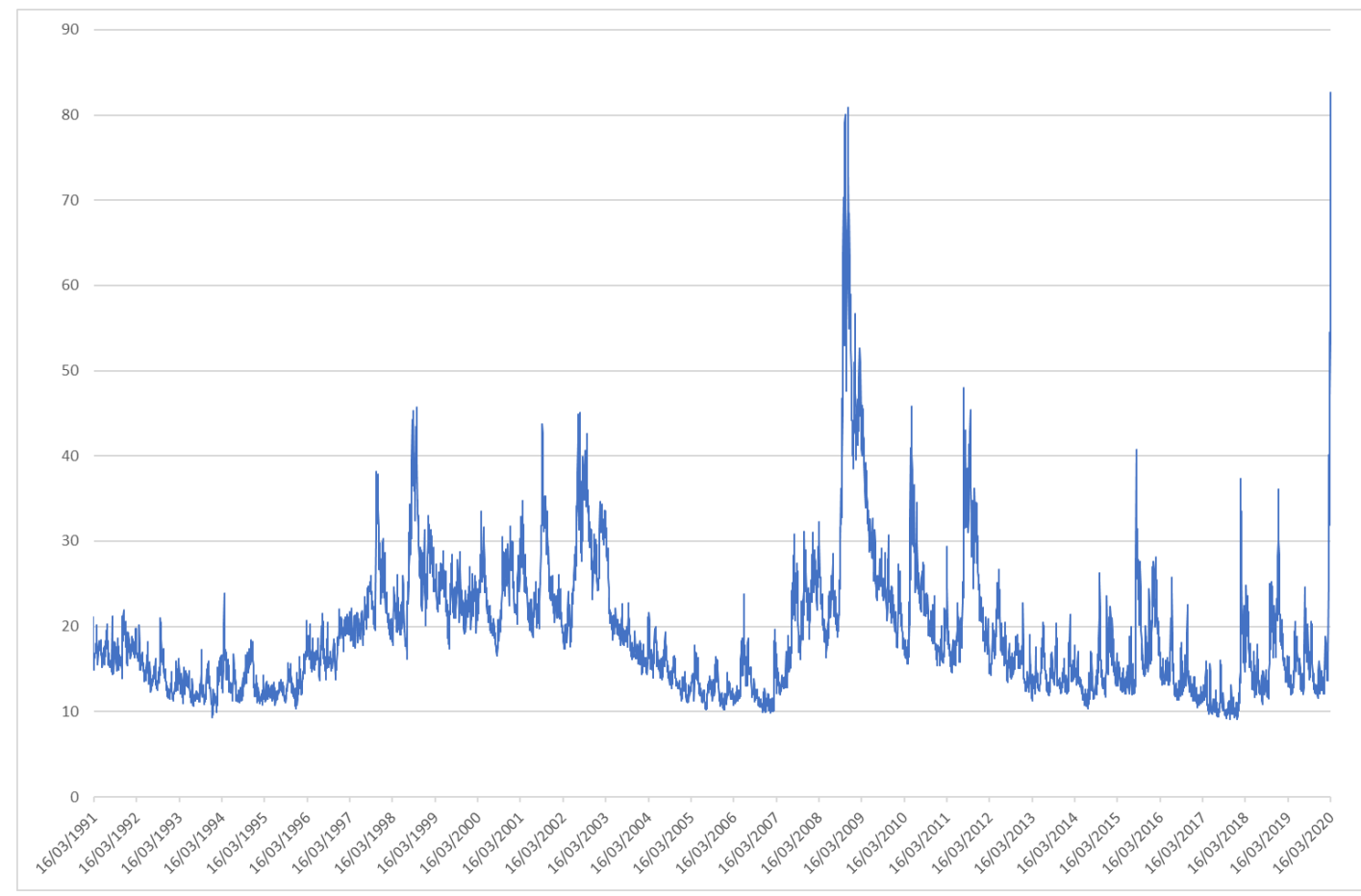

Source: http://www.cboe.com/micro/vix/historical.aspx 
Figure 9 shows the implied volatility in markets. The VIX long-term average is approximately $20 \%$. However, it can clearly be seen that it rose significantly in the aftermath of the 2008/9 financial crisis, thus reflecting investors' uncertainty about the future. Nowadays, it is actually above those levels.

All prior crisis have been triggered by other events (sovereign debt crisis, LTCM default, dot-com bubble, banking crisis, program trading collapse, political events, wars, etc.). And in many past crises, central banks had at their disposal tools to prevent further damages.

None of the previous examples were in periods where the starting point of interest rates was so low (and in some cases negative). This could raise concern in the markets that there is little room for an effective policy response.

\section{Key assumptions in the forecasts}

In this uncertain environment, it is difficult to forecast the economic impact of the COVID-19 crisis. As explained above, there is no historical benchmark that we can use directly. Indeed, no prior crisis has started like this: a health event, global, that influences supply and demand simultaneously, in a period when central banks have no firepower left (due to the zero or negative interest rates already in place). In any case, we need to use available data to the best extent possible in order to formulate key assumptions in the forecasting model.

The yearly GDP of a country is split, ignoring seasonality, into months. We then need assumptions as to the duration of the current shutdown of economic activity. In the base scenario, the significant shutdown of economic activity is assumed to last from mid-March to mid-May. That is more or less the duration of the toughest control measures in China. And as of the date of this report, several countries have announced complete lockdowns until the end of April. In this scenario, May is then a gradual recovery period. This is the base assumption for the majority of sectors. But for those that are tourism-related, it is assumed that the recovery phase will take a bit longer (May and June). After the recovery period, that economic activity returns to the normal expected path. That is, under the base case scenario, we will assume that, for instance, the 
number of cars sold in August 2020 will return to the amount forecasted for the month back in early 2020.

At the time of this report, the duration of the current crisis is unknown. These assumptions could lead to a mildly conservative scenario, as there is no guarantee economic activity will resume with normality once the containment measures are removed. Indeed, given the significant shock to labor and product markets during the crisis months, with some probability, the post-crisis months will be below the expectations set prior to the crisis. In our model, we are ignoring this (more negative) hypothesis.

To base several estimations, we also use data from previous sections, on the Chinese and global economies, global trade, plus high-frequency data from different sources, including sectorspecific impacts. The results are also calibrated with the reduction in consumption expenditure during the SARS outbreak in China. Moreover, our model is further calibrated using the available data for China in the first months of 2020, in terms of its consumption, production, investment, retail sales, etc., during the lockdown months. This may lead to an underestimation. Indeed, Chinese consumers are heavy users of e-commerce. This means that in countries where ecommerce is less developed, the impacts on consumption may be higher.

For each country, the model uses GDP decomposed into its' different economic sectors. During the crisis months, it is assumed that service-oriented sectors will be more impacted than agriculture or industry. As explained in prior sections, with fewer tourists and lower consumption overall, airlines, retail, hospitality and entertainment sectors are all expected to suffer greatly from the outbreak. Stock market data in previous figures is consistent with this assumption, too. Overall, this suggests that the economic cost of a recession are unequally distributed. Given the different industrial composition of countries, impacts will be felt differently around the globe. For instance, the model assumes that countries that have a larger tourism sector (as a \% of GDP) will be more severely affected than countries that are more industrial focused. Given the documented disruption to trade flows, the model also assumes that countries more reliant on exports will suffer disproportionally more. 
The model does not consider direct and indirect health costs, and so may underestimate the true economic damage. In reality, shocks to the labor supply in each country will occur. And they will vary with the mortality rate due to infections and delays in returning to work for the infected. There will also be absenteeism from work due to family members who are infected. Finally, the model does not include possible spillovers to the financial sector. If a significant disruption to the financial sector occurs, this will obviously impact firms with high levels of financial dependence.

\section{Main results}

\section{1- The COVID-19 economic impact: mild scenario}

Table 1 shows the economic shock posed by the current COVID-19 crisis (and a confidence interval), expressed as a percentage of GDP for each country. They provide an estimate of the overall economic cost of the crisis under many assumptions (previous sections). Chief among them, in this scenario, the shutdown is assumed to be 1.5 months, with May being a gradual recovery month.

In the base scenario, in which the economic situation would be normalized by the end of May, the economic impact of the crisis ranges from 3.5 to $6 \%$ depending on the country. For instance, in the U.S., the crisis is expected to cost nearly $4 \%$ of its GDP. Overall, for all countries analyzed, an average economic impact of $-4.5 \%$ of GDP is expected (median $=-4.4 \%$ ). The model takes into account the different compositions of GDP in different countries. For instance, the higher the weight of tourism, the higher the impact of the crisis. In addition, supply chain disruptions, and a steep fall in global trade, exert further pressure on countries highly dependent on foreign trade. 
Table 1: Economic impact (\% of GDP) - 1.5 months scenario

\begin{tabular}{|l|c|c|}
\multicolumn{1}{c}{} & Economic Impact & confidence margin \\
\hline Argentina & $-4.3 \%$ & [from $-5.7 \%$ to $-3.0 \%]$ \\
\hline Australia & $-4.4 \%$ & [from $-5.8 \%$ to $-3.1 \%]$ \\
\hline Austria & $-5.5 \%$ & [from $-7.1 \%$ to $-3.9 \%]$ \\
\hline Belgium & $-4.3 \%$ & [from $-6.0 \%$ to $-2.6 \%]$ \\
\hline Brazil & $-3.9 \%$ & [from $-5.3 \%$ to $-2.7 \%]$ \\
\hline Canada & $-3.9 \%$ & [from $-5.3 \%$ to $-2.5 \%]$ \\
\hline China & $-4.3 \%$ & [from $-5.6 \%$ to $-2.9 \%]$ \\
\hline Czech Republic & $-4.6 \%$ & [from $-6.3 \%$ to $-2.9 \%]$ \\
\hline France & $-4.3 \%$ & [from $-5.7 \%$ to $-2.9 \%]$ \\
\hline Germany & $-4.8 \%$ & [from $-6.3 \%$ to $-3.2 \%]$ \\
\hline Greece & $-6.2 \%$ & [from $-7.7 \%$ to $-4.7 \%]$ \\
\hline India & $-4.0 \%$ & [from $-5.3 \%$ to $-2.7 \%]$ \\
\hline Ireland & $-4.8 \%$ & [from $-6.8 \%$ to $-2.8 \%]$ \\
\hline Italy & $-5.0 \%$ & [from $-6.4 \%$ to $-3.5 \%]$ \\
\hline Japan & $-3.6 \%$ & [from $-4.9 \%$ to $-2.3 \%]$ \\
\hline Mexico & $-5.4 \%$ & [from $-6.9 \%$ to $-3.9 \%]$ \\
\hline Netherlands & $-4.2 \%$ & [from $-6.0 \%$ to $-2.5 \%]$ \\
\hline Norway & $-4.4 \%$ & [from $-5.9 \%$ to $-3.0 \%]$ \\
\hline Poland & $-3.9 \%$ & [from $-5.4 \%$ to $-2.3 \%]$ \\
\hline Portugal & $-5.9 \%$ & [from $-7.5 \%$ to $-4.4 \%]$ \\
\hline Russian Federation & $-3.6 \%$ & [from $-5.0 \%$ to $-2.2 \%]$ \\
\hline Saudi Arabia & $-4.4 \%$ & [from $-5.8 \%$ to $-2.9 \%]$ \\
\hline South Africa & $-4.3 \%$ & [from $-5.7 \%$ to $-2.9 \%]$ \\
\hline South Korea & $-3.8 \%$ & [from $-5.3 \%$ to $-2.3 \%]$ \\
\hline Spain & $-5.2 \%$ & [from $-6.7 \%$ to $-3.7 \%]$ \\
\hline Sweden & $-4.5 \%$ & [from $-6.1 \%$ to $-3.0 \%]$ \\
\hline Switzerland & $-4.6 \%$ & [from $-6.2 \%$ to $-3.0 \%]$ \\
\hline Turkey & $-4.6 \%$ & [from $-6.1 \%$ to $-3.2 \%]$ \\
\hline United Kingdom & $-4.5 \%$ & [from $-6.0 \%$ to $-3.1 \%]$ \\
\hline United States & $-3.8 \%$ & [from $-5.1 \%$ to $-2.5 \%]$ \\
\hline
\end{tabular}




\section{2- Estimated GDP growth for different countries}

In this section, we compute the expected GDP growth for each country under the base scenario.

Table 2Table 2: shows the results.

Table 2: Estimated GDP growth in 2020 (and confidence margin) - 1.5 months scenario

\begin{tabular}{|c|c|c|}
\hline & Growth in GDP & confidence margin \\
\hline Argentina & $-5.0 \%$ & [from $-6.4 \%$ to $-3.7 \%$ ] \\
\hline Australia & $-2.2 \%$ & [from $-3.6 \%$ to $-0.8 \%$ ] \\
\hline Austria & $-3.8 \%$ & [from $-5.4 \%$ to $-2.2 \%$ ] \\
\hline Belgium & $-3.0 \%$ & [from $-4.7 \%$ to $-1.3 \%$ ] \\
\hline Brazil & $-1.9 \%$ & [from $-3.2 \%$ to $-0.6 \%$ ] \\
\hline Canada & $-2.1 \%$ & [from $-3.5 \%$ to $-0.7 \%$ ] \\
\hline China & $1.6 \%$ & [from $0.2 \%$ to $2.9 \%$ ] \\
\hline Czech Republic & $-2.0 \%$ & [from $-3.7 \%$ to $-0.3 \%$ ] \\
\hline France & $-3.0 \%$ & [from $-4.5 \%$ to $-1.6 \%$ ] \\
\hline Germany & $-3.5 \%$ & [from $-5.1 \%$ to $-2.0 \%$ ] \\
\hline Greece & $-3.9 \%$ & [from $-5.5 \%$ to $-2.4 \%$ ] \\
\hline India & $3.1 \%$ & [from $1.7 \%$ to $4.3 \%$ ] \\
\hline Ireland & $-1.3 \%$ & [from $-3.3 \%$ to $0.7 \%$ ] \\
\hline Italy & $-4.5 \%$ & [from $-5.9 \%$ to $-3.0 \%$ ] \\
\hline Japan & $-3.1 \%$ & [from $-4.5 \%$ to $-1.9 \%$ ] \\
\hline Mexico & $-4.1 \%$ & [from $-5.6 \%$ to $-2.6 \%$ ] \\
\hline Netherlands & $-2.6 \%$ & [from $-4.3 \%$ to $-0.9 \%$ ] \\
\hline Norway & $-2.0 \%$ & [from $-3.5 \%$ to $-0.5 \%$ ] \\
\hline Poland & $-0.8 \%$ & [from $-2.3 \%$ to $0.7 \%$ ] \\
\hline Portugal & $-4.3 \%$ & [from $-5.9 \%$ to $-2.8 \%$ ] \\
\hline Russian Federation & $-1.7 \%$ & [from $-3.1 \%$ to $-0.4 \%$ ] \\
\hline Saudi Arabia & $-2.2 \%$ & [from $-3.7 \%$ to $-0.8 \%$ ] \\
\hline South Africa & $-3.2 \%$ & [from $-4.6 \%$ to $-1.8 \%$ ] \\
\hline South Korea & $-1.6 \%$ & [from $-3.0 \%$ to $-0.1 \%$ ] \\
\hline Spain & $-3.4 \%$ & [from $-4.9 \%$ to $-1.9 \%$ ] \\
\hline Sweden & $-3.1 \%$ & [from $-4.6 \%$ to $-1.6 \%$ ] \\
\hline Switzerland & $-3.3 \%$ & [from $-5.0 \%$ to $-1.7 \%$ ] \\
\hline Turkey & $-1.7 \%$ & [from $-3.1 \%$ to $-0.3 \%$ ] \\
\hline United Kingdom & $-3.1 \%$ & [from $-4.5 \%$ to $-1.7 \%$ ] \\
\hline United States & $-1.7 \%$ & [from $-3.0 \%$ to $-0.4 \%$ ] \\
\hline
\end{tabular}


On average, for all countries analyzed, the expected GDP growth in 2020 is $-2.5 \%$ (median = 2.8\%). The expected GDP growth is computed taking into account the (pre-crisis) expected 2020 GDP growth for each country (IMF end-2019 estimates) and the above-mentioned economic costs of the COVID-19 crisis (Table 1, 1.5 months scenario). For instance, France, was previously forecasted to grow by $1.3 \%$ in 2020 . Taking into account the economic impact of the crisis (-4.3\%), the estimated growth rate of the French GDP is $-3 \%$.

The U.S. is expected to enter in a recession, with a GDP growth of $-1.7 \%$. It seems inevitable now that the economic downturn due to the coronavirus will put an end to the longest-running expansion in U.S. history.

Once again, the impact of the current crisis will be different around the world. China will, in this scenario, still have a positive growth of GDP (pre-crisis 6\%, now less than $2 \%$ ). On the other hand, most European countries will face significant recessions. Pre-crisis, European countries were not expected to grow much. And now, they see contractions of their GDP of $-3 \%$ to $-4 \%$. Judging from prior recessions, a decline in GDP of this magnitude will significantly increase unemployment, and public deficits. Overall, this scenario leads, for these countries, to an average growth in 2020 of $-2.5 \%$. This is substantially below the close to $+3 \%$ growth rate seen in 2019 .

The estimates in this section assume that, once the containment measures are removed, economic activity returns to normality. It seems however possible that the economic pain will go on for longer than the containment period. Having imposed bans and restrictions, governments and public-sector bodies will be extremely cautious about removing them, and possibly, will remove them gradually, for certain sectors/activities only. Also, given the potential shock to labor and product markets during the crisis months, it is possible that the post-crisis months will be below the expectations set prior to the crisis. In our model, we are ignoring this (more negative) hypothesis.

\section{3- Other scenarios}

At the time of this report, the duration of the current crisis is unknown. Moreover, as of the date of this report, several countries have announced complete lockdowns until the end of April, 
beginning of May. This means the results of sections 6.1 and 6.2 may be conservative, as there is no guarantee economic activity will resume with normality in May.

\section{Shutdown of three months}

The following table provides estimates of the impact if the crisis continues until mid-June. With a gradual recovery of economic activity until early-July.

Table 3: Estimated GDP growth in 2020, assuming shutdown lasts 3 months

\begin{tabular}{|c|c|c|}
\hline & Growth in GDP & confidence margin \\
\hline Argentina & $-8.5 \%$ & [from $-10.8 \%$ to $-6.3 \%$ ] \\
\hline Australia & $-5.8 \%$ & [from $-8.1 \%$ to $-3.5 \%$ ] \\
\hline Austria & $-8.1 \%$ & [from $-10.8 \%$ to $-5.4 \%$ ] \\
\hline Belgium & $-6.8 \%$ & [from $-9.7 \%$ to $-3.9 \%$ ] \\
\hline Brazil & $-5.2 \%$ & [from $-7.4 \%$ to $-3.0 \%$ ] \\
\hline Canada & $-5.5 \%$ & [from $-7.9 \%$ to $-3.1 \%$ ] \\
\hline China & $-1.9 \%$ & [from $-4.2 \%$ to $0.3 \%$ ] \\
\hline Czech Republic & $-5.9 \%$ & [from $-8.8 \%$ to $-3.1 \%$ ] \\
\hline France & $-6.6 \%$ & [from $-9.0 \%$ to $-4.2 \%$ ] \\
\hline Germany & $-7.4 \%$ & [from $-10.0 \%$ to $-4.9 \%$ ] \\
\hline Greece & $-8.6 \%$ & [from $-11.1 \%$ to $-6.1 \%$ ] \\
\hline India & $-0.2 \%$ & [from $-2.5 \%$ to $2.0 \%$ ] \\
\hline Ireland & $-5.5 \%$ & [from $-8.8 \%$ to $-2.2 \%$ ] \\
\hline Italy & $-8.4 \%$ & [from $-10.9 \%$ to $-6.0 \%$ ] \\
\hline Japan & $-6.3 \%$ & [from $-8.5 \%$ to $-4.1 \%$ ] \\
\hline Mexico & $-8.3 \%$ & [from $-10.8 \%$ to $-5.8 \%$ ] \\
\hline Netherlands & $-6.3 \%$ & [from $-9.3 \%$ to $-3.4 \%$ ] \\
\hline Norway & $-5.7 \%$ & [from $-8.2 \%$ to $-3.2 \%$ ] \\
\hline Poland & $-4.2 \%$ & [from $-6.9 \%$ to $-1.6 \%$ ] \\
\hline Portugal & $-8.8 \%$ & [from $-11.4 \%$ to $-6.3 \%$ ] \\
\hline Russian Federation & $-4.9 \%$ & [from $-7.3 \%$ to $-2.6 \%$ ] \\
\hline Saudi Arabia & $-5.9 \%$ & [from $-8.4 \%$ to $-3.4 \%$ ] \\
\hline South Africa & $-6.8 \%$ & [from $-9.2 \%$ to $-4.4 \%$ ] \\
\hline South Korea & $-4.9 \%$ & [from $-7.4 \%$ to $-2.4 \%$ ] \\
\hline Spain & $-7.5 \%$ & [from $-10.0 \%$ to $-5.0 \%$ ] \\
\hline Sweden & $-6.8 \%$ & [from $-9.4 \%$ to $-4.3 \%$ ] \\
\hline Switzerland & $-7.2 \%$ & [from $-10.0 \%$ to $-4.5 \%$ ] \\
\hline Turkey & $-5.4 \%$ & [from $-7.8 \%$ to $-3.0 \%$ ] \\
\hline United Kingdom & $-6.8 \%$ & [from $-9.2 \%$ to $-4.4 \%$ ] \\
\hline United States & $-5.0 \%$ & [from $-7.2 \%$ to $-2.8 \%$ ] \\
\hline
\end{tabular}


Overall, this second scenario leads to a contraction in GDP in all countries. On average, for all countries analyzed, the expected GDP growth in 2020 is $-6.2 \%$ (median $=-6.3 \%$ ). Once again, the impact of the crisis will be different around the world. If extreme COVID-19-related measures last until the end of June 2020, the U.S. will see its GDP fall by 5\%. Germany, Greece, Italy, Portugal and Spain growth will see their GDP decline by -7\% or more. On average, each additional month of crisis costs $2.5-3 \%$ of global GDP.

\section{Shutdown of 4.5 months}

Table 4 looks at a more extreme scenario where the shutdown lasts until the end of July. With a gradual recovery of economic activity occurring in August.

In this more extreme scenario, we would face some of the most challenging economic conditions ever. No country would be left unharmed. The average decline in GDP would be close to $10.4 \%$ (median $=-10.7 \%)$. As expected, countries that are highly reliant on tourism are even more affected in this scenario, where the summer is almost entirely lost. Similarly, countries highly dependent on foreign trade are more negatively affected. And the decrease in GDP could, in some cases, be higher than $12 \%$. 
Table 4: Estimated GDP growth in 2020, assuming shutdown lasts 4.5 months

\begin{tabular}{|c|c|c|}
\hline & Growth in GDP & confidence margin \\
\hline Argentina & $-12.4 \%$ & [from $-16.6 \%$ to $-9.1 \%$ ] \\
\hline Australia & $-9.8 \%$ & [from $-14.1 \%$ to $-6.3 \%$ ] \\
\hline Austria & $-13.1 \%$ & [from $-18.0 \%$ to $-8.9 \%$ ] \\
\hline Belgium & $-11.3 \%$ & [from $-16.4 \%$ to $-6.5 \%$ ] \\
\hline Brazil & $-8.8 \%$ & [from $-13.0 \%$ to $-5.5 \%$ ] \\
\hline Canada & $-9.2 \%$ & [from $-13.6 \%$ to $-5.5 \%$ ] \\
\hline China & $-5.8 \%$ & [from $-10.0 \%$ to $-2.4 \%$ ] \\
\hline Czech Republic & $-10.6 \%$ & [from $-15.6 \%$ to $-5.8 \%$ ] \\
\hline France & $-10.6 \%$ & [from $-15.0 \%$ to $-6.9 \%$ ] \\
\hline Germany & $-11.9 \%$ & [from $-16.6 \%$ to $-7.9 \%$ ] \\
\hline Greece & $-13.8 \%$ & [from $-18.6 \%$ to $-10.0 \%$ ] \\
\hline India & $-3.8 \%$ & [from $-8.0 \%$ to $-0.5 \%$ ] \\
\hline Ireland & $-10.8 \%$ & [from $-16.3 \%$ to $-5.0 \%$ ] \\
\hline Italy & $-12.9 \%$ & [from $-17.4 \%$ to $-9.2 \%$ ] \\
\hline Japan & $-9.7 \%$ & [from $-13.8 \%$ to $-6.4 \%$ ] \\
\hline Mexico & $-13.0 \%$ & [from $-17.7 \%$ to $-9.2 \%$ ] \\
\hline Netherlands & $-10.8 \%$ & [from $-15.9 \%$ to $-6.0 \%$ ] \\
\hline Norway & $-9.9 \%$ & [from $-14.4 \%$ to $-6.0 \%$ ] \\
\hline Poland & $-8.2 \%$ & [from $-12.9 \%$ to $-4.0 \%$ ] \\
\hline Portugal & $-14.0 \%$ & [from $-18.8 \%$ to $-10.0 \%$ ] \\
\hline Russian Federation & $-8.5 \%$ & [from $-12.8 \%$ to $-4.9 \%$ ] \\
\hline Saudi Arabia & $-10.0 \%$ & [from $-14.5 \%$ to $-6.1 \%$ ] \\
\hline South Africa & $-10.8 \%$ & [from $-15.2 \%$ to $-7.2 \%$ ] \\
\hline South Korea & $-8.7 \%$ & [from $-13.2 \%$ to $-4.8 \%$ ] \\
\hline Spain & $-12.1 \%$ & [from $-16.7 \%$ to $-8.3 \%$ ] \\
\hline Sweden & $-11.2 \%$ & [from $-15.8 \%$ to $-7.1 \%$ ] \\
\hline Switzerland & $-11.8 \%$ & [from $-16.6 \%$ to $-7.3 \%$ ] \\
\hline Turkey & $-9.6 \%$ & [from $-14.0 \%$ to $-6.0 \%$ ] \\
\hline United Kingdom & $-11.0 \%$ & [from $-15.4 \%$ to $-7.3 \%$ ] \\
\hline United States & $-8.5 \%$ & [from $-12.6 \%$ to $-5.3 \%$ ] \\
\hline
\end{tabular}




\section{Concluding comments: What lies ahead}

The COVID-19 crisis spread rapidly throughout the world last month. We are facing a totally new type of crisis. In this case, the health risk (actual mortality and infection rates) is not necessarily correlated with the economic risk to the global economy. Historically, global trade has allowed countries to share risk. This time, this channel is not likely to help much. This is a global shock when the world is much more integrated. Interest rates are at historical lows, and the current crisis is also generating spillover effects throughout supply chains.

A global recession now seems inevitable. But how deep and long the downturn will be depends on the success of measures taken to prevent the spread of COVID-19, the effects of government policies to alleviate liquidity problems in SMEs and to support families under financial distress. It also depends upon how companies react and prepare for the re-start of economic activities. And, above all, it depends on how long the current lockdowns will last.

At the date of this report, the duration of the lockdown, as well as how the recovery will take place is still unknown. That is why several scenarios are used. In the base scenario, GDP growth would take a hit, ranging from 3-6\% depending on the country. As a result, in the sample of 30 countries covered, we would see a median decline in GDP in 2020 of $-2.8 \%$. In other scenarios, GDP can fall more than $10 \%$, and in some countries, more than $15 \%$.

Figure 10: Estimated GDP growth in 2020 under the different scenarios (Median)

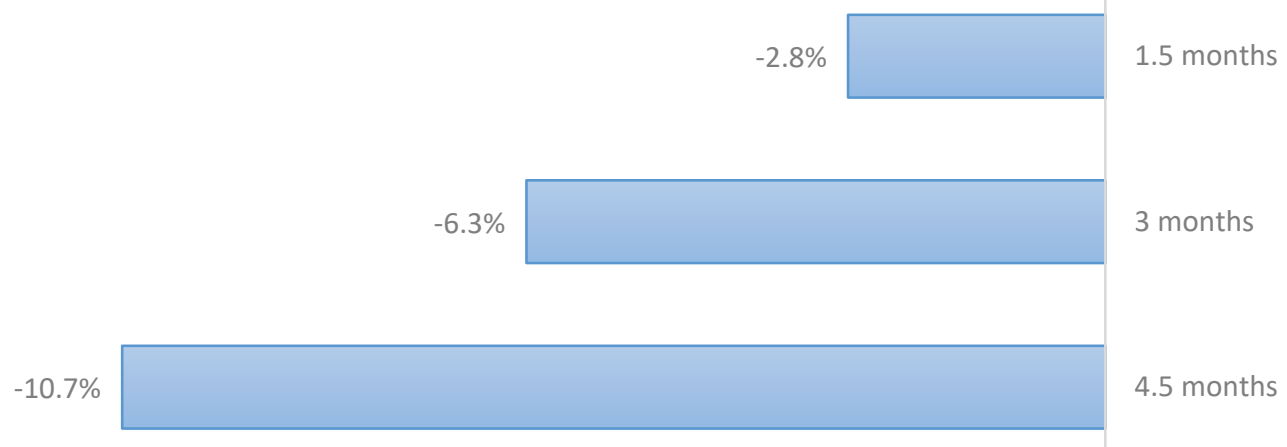


The results suggest that on average, each additional month of crisis costs $2.5-3 \%$ of global GDP. The economic costs of a recession are unequally distributed. We already know many of the most affected sectors. Also, based on prior crises, it seems that younger and less educated workers will, unfortunately, be more likely to lose their jobs.

No one can accurately predict the final financial damage from COVID-19. This obviously depends on timing, the severity of the pandemic into future weeks/months, and countries' policy responses. Also, hopes of a coronavirus vaccine mount, which would be welcome news. If the ongoing crisis lasts until the end of the summer, the global economy faces the gravest threat seen in the last two centuries. 


\section{Main references, news articles, and other sources}

Amaro, S. (2020, March 17) "Macron warns 'we are at war' as France unveils $\$ 50$ billion in coronavirus measures". CNBC. Available at: https://www.cnbc.com/2020/03/17/hopes-of-acoronavirus-vaccine-mount-as-three-key-biotech-players-make-progress.html. [Accessed: 19 March 2020]

Barry, John M. (2004). “The Great Influenza: The Epic Story of the Deadliest Plague in History”. New York: Penguin Group.

Bhattarai A., Long, H. and Siegel, R. (2020, March 11) "The first US layoffs from the coronavirus are here. Stars and Stripes". Available at: https://www.stripes.com/news/us/the-first-us-layoffs-fromthe-coronavirus-are-here-1.622069. [Accessed: 19 March 2020]

Bloom D. E., Cadarette D. and Sevilla J.P., "The Economic Risks and Impacts of Epidemics", International Monetary Fund, F\&D Magazine, June 2018.

"China's Economy Suffers Historic Slump Due to Virus Shutdown". (2020, March 16). Bloomberg News. Available at: https://www.bloomberg.com/news/articles/2020-03-16/chinamanufacturing-and-retail-contract-for-first-time-on-virus. [Accessed: 19 March 2020]

Chou, J., N.-F. Kuo, et al., 2004. "Potential Impacts of the SARS Outbreak on Taiwan's Economy". Asian Economic Papers 3(1), 84-112.

"Cineplex closing all theatres across Canada due to COVID-19 concerns". (2020, March 16). City News. Available at: https://toronto.citynews.ca/2020/03/16/cineplex-closing-all-theatres-acrosscanada-due-to-covid-19-concerns/. [Accessed: 19 March 2020]

Congressional Budget Office (2005) "A Potential Influenza Pandemic: Possible Macroeconomic Effects and Policy Issues". CBO Washington DC.

Crosby, Alfred W. (2003). “America's Forgotten Pandemic: The Influenza of 1918". Cambridge University Press.

Dean, J. (2020, March 17) "American GDP to shrink 5\%, warns Goldman Sachs". The Times. Available at: https://www.thetimes.co.uk/article/american-gdp-to-shrink-5-warns-goldmansachs-ljh2fgmvk. [Accessed: 19 March 2020]

“Ebola situation report - 16 March 2016. Geneva: World Health Organization" (2016.) Available from: http://apps.who.int/iris/bitstream/10665/204629/1/ebolasitrep_16Mar2016 eng.pdf?ua= 1 [cited 2016 Apr 2].

Esposito, A. (2020, March 16) "The Worst Hit Equity Sectors in 2020". Morningstar. Available at_ https://www.morningstar.co.uk/uk/news/200469/the-worst-hit-equity-sectors-in-2020.aspx. [Accessed: 19 March 2020]

Fan V. Y., Jamison D. T. \& Summers L. H. (2018) “Pandemic risk: how large are the expected losses?" Bulletin of the World Health Organization. 
Fan V.Y., Jamison D.T., Summers L.H. (2015) “The Inclusive Cost of Pandemic Influenza Risk". NBER Work Pap N. 22137

Fernandes, N. (2017) "Finance for Executives: A Practical Guide for Managers". 2nd Edition, Chapter 13.

Global Preparedness Monitoring Board (2019). "A world at risk: annual report on global preparedness for health emergencies". Geneva: World Health Organization.

Haacker, M., (2002a). "The economic consequences of HIV/AIDS in Southern Africa". IMF Working Paper W/02/38, 41-95.

Hai, W., Z. Zhao, et al. (2004). "The Short-Term Impact of SARS on the Chinese Economy". Asian Economic Papers 3(1), 57-61.

Huber, C., Finelli, L. \& Stevens, W. (2018). "The Economic and Social Burden of the 2014 Ebola Outbreak in West Africa". The Journal of Infectious Diseases 2018;0000:S1-7. https://academic.oup.com/jid/advance-article/doi/10.1093/infdis/jiy213/5129071

“Italian Car Sales 'Could Fall over 15\%' amid Coronavirus Spread”. (2020, March 19). The New York Times. Available at: https://www.reuters.com/article/us-health-coronavirus-italy-autos/italiancar-sales-could-fall-over-15-amid-coronavirus-spread-idUSKBN20T28B. [Accessed: 19 March 2020]

JP Morgan (2019, December 19) "Global Market Outlook 2019: Higher Growth Outside of US, Lower Returns". Available at: https://www.jpmorgan.com/global/research/global-marketoutlook-2020. [Accessed: 19 March 2020]

"China Retail Sales, Industrial Production Plunge". (2020, March 16). Bloomberg Markets. Available at: $\quad$ https://www.bloomberg.com/news/videos/2020-03-16/china-retail-sales-industrialproduction-plunge-video. [Accessed: 19 March 2020]

Jennings, R. (2020, March 17) “'Unprecedented' Lockdown of Manila Expected to Cut Philippine Economic Growth". The News Available at: https://international.thenewslens.com/article/132572. [Accessed: 19 March 2020]

Kostova D., Cassell C.H., Redd J.T., Williams D.E., Singh T., Martel L.D., Bunnell R.E. (2010) “Longdistance effects of epidemics: Assessing the link between the 2014 West Africa Ebola outbreak and U.S. exports and employment", Health Economics, Vol. 28 No. 11, pp. 1248-1261.

Lee J-W and W. McKibbin (2004) "Globalization and Disease: The Case of SARS". Asian Economic Papers Vol. 3 No. 1, pp. 113-131.

Lo, K. (2020, March 1) "Coronavirus: China says over 90 per cent of state firms back in business after manufacturing index hits all-time low". South China Morning Post. Available at: https://www.scmp.com/economy/china-economy/article/3053073/coronavirus-china-says-90cent-state-firms-back-business.[Accessed: 19 March 2020]

McKibbin W. and A. Sidorenko (2006) "Global Macroeconomic Consequences of Pandemic Influenza". Brookings. Available at: https://www.brookings.edu/research/globalmacroeconomic-consequences-of-pandemic-influenza/. [Accessed: 20 March 2020) 
Morris, K. and Karmin, C. (2020, March 13) "Hotels Turn to Layoffs, Room Rate Cuts as Business Staggers". The Wall Street Journal. Available at: https://www.wsj.com/articles/hotels-turn-tolayoffs-room-rate-cuts-as-business-staggers-11584108223. [Accessed: 19 March 2020]

OECD (2020, 2 March) "Global economy faces gravest threat since the crisis as coronavirus spreads". Available at: http://www.oecd.org/economy/global-economy-faces-gravest-threatsince-the-crisis-as-coronavirus-spreads.htm. [Accessed: 19 March 2020]

Payme, A. (2020, March 13) "Germany has offered companies 'unlimited' loans to stop them from collapsing because of the coronavirus pandemic". Business Insider. Available at: https://www.businessinsider.com/coronavirus-germany-offers-affected-companies-unlimitedloans-covid-19-2020-3?IR=T. [Accessed: 19 March 2020]

Roberts, C. (2020, March 17) “Europe Resorts to Unprecedented Restrictions on Public Life". CNN Money Switzerland. Available at: https://www.cnnmoney.ch/shows/big-picture/videos/europeresorts-unprecedented-restrictions-public-life. [Accessed: 19 March 2020]

Ruffino, G. (2020, March 12) "Coronavirus causes Swiss Watch makers more Grief”. CNN Money Switzerland. Available at: https://www.cnnmoney.ch/shows/big-picture/videos/coronaviruscauses-swiss-watchmakers-more-grief. [Accessed: 19 March 2020]

Solsvick, T. (2020, March 16) "Norwegian Air to cancel $85 \%$ of flights and lay off $90 \%$ of staff". Reuters. Available at: https://www.reuters.com/article/us-health-coronavirusnorwegianair/norwegian-air-to-cancel-85-of-flights-and-lay-off-90-of-staff-idUSKBN2132F7. [Accessed: 19 March 2020]

Sui, A. and Y. C. R. Wong, 2004. "Economic Impact of SARS: The Case of Hong-Kong". Asian Economic Papers Vol. 3 No. 1), 62-83.

Tatelbaum, J. (2020, March 17) "Hopes of a coronavirus vaccine mount as three key biotech players make progress". CNBC. Available at: https://www.cnbc.com/2020/03/17/hopes-of-acoronavirus-vaccine-mount-as-three-key-biotech-players-make-progress.html. [Accessed: 19 March 2020]

Taylor, D. and Schwartz, J. (2020, March 17) "Volkswagen suspends production as coronavirus hits sales". Reuters. Available at: https://www.reuters.com/article/us-volkswagen-results2019/volkswagen-suspends-production-as-coronavirus-hits-sales-idUSKBN21400F. [Accessed: 19 March 2020]

Volkman, E. (2020, March 16) "MGM Closes All US Casino Resorts". The Motley Fool. Available at: https://www.fool.com/investing/2020/03/16/mgm-closes-all-casino-resorts.aspx. [Accessed: 19 March 2020]

Voytko, L. (2020, March 18) "Coronavirus Layoffs: Marriott, Danny Meyer Restaurants Join List Of Companies Shedding Jobs Due To The Pandemic". Forbs. Available at: https://www.forbes.com/sites/lisettevoytko/2020/03/18/coronavirus-layoffs-marriott-lauraashley-join-list-of-companies-shedding-jobs-due-to-the-pandemic/\#599f8b42183e. [Accessed: 19 March 2020] 
Wakket, M. (2020, February 25) "As coronavirus goes global, Maersk prepares for a major financial hit". The Load Star. Available at: https://theloadstar.com/as-coronavirus-goes-globalmaersk-prepares-for-a-major-financial-hit/. [Accessed: 19 March 2020]

Walsh, D. (2020, March 17) "Travel giant in lockdown as it applies for state aid". The Times. Available at: https://www.thetimes.co.uk/article/travel-giant-in-lockdown-as-it-applies-forstate-aid-psk68650k. [Accessed: 19 March 2020]

Wilton, P. (1993). "Spanish flu outdid WWI in number of lives claimed". Canadian Medical Association Journal 148(11): 2036-7.

Wink, B. (2020, March 13) "JP Morgan officially forecasts a coronavirus-driven recession will rock the US and Europe by July. Market Insider". Available at: https://markets.businessinsider.com/news/stocks/coronavirus-fuel-recession-forecast-useurope-economic-july-market-jpmorgan-2020-3-1028994637. [Accessed: 10 March 2020]

World Bank Group (2019) "Pandemic Preparedness Financing - Status update". World Bank, September 2019.

World Bank Group (2019) "Pandemic Preparedness Financing" - Status update'”. Washington, DC: World Bank Group.

World Bank Group (2017) "From panic and neglect to investing in health security: financing pandemic preparedness at a national level". Washington, DC: World Bank Group

World Bank Group (2019). “Pandemic Preparedness Financing-STATUS UPDATE, June 2019” Commissioned paper by the GPMB, www.who. int/gpmb.

World Health Organization (2019) “A World at Risk'. Annual report on global preparedness for health emergencies". Geneva: World Health Organization.

Ziady, A. (2020, February 29) "Maersk operates massive container ships. It's canceled 50 sailings over coronavirus". CNN Business. Available at: https://edition.cnn.com/2020/02/20/business/maersk-earnings-coronavirus/index.html.

[Accessed: 19 March 2020] 